\title{
Carbonate-rich dyke in Roztoky Intrusive Complex - an evidence for carbonatite magmatism in the Eger Rift?
}

\author{
Vladislav RAPPRICH*, Yulia V. KOCHERGINA, Tomáš MAGNA, František LAUFEK, Patricie \\ HALODOVÁ, František BŮZEK
}

Czech Geological Survey, Klárov 3, 11821 Prague 1, Czech Republic; vladislav.rapprich@geology.cz

* Corresponding author

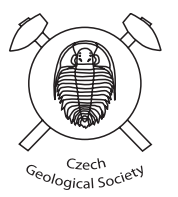

The possible presence of carbonatites in the Eger Rift (NW Bohemian Massif, Czech Republic) has been debated for several decades without any apparent resolution. Here, we document an almost $2 \mathrm{~m}$ thick dyke of a silicocarbonatite (23 wt. \% $\mathrm{SiO}_{2}, 27$ wt. \% $\mathrm{CO}_{2}$ ) in the R2 (Roztoky nad Labem) drilling at the depth of 152.9-154.8 m. Despite the fact that the silicocarbonatite is associated with alkaline intrusive complex, its content of alkalis is rather low $\left(\mathrm{Na}_{2} \mathrm{O}+\right.$ $\mathrm{K}_{2} \mathrm{O}=2.5$ wt. $\left.\%\right)$, as are $\operatorname{REE}(\Sigma \mathrm{REE}=82.6 \mathrm{ppm})$. The stable isotope signature $\left(\delta^{18} \mathrm{O}=7.43 \%, \delta^{13} \mathrm{C}=-2.46 \%\right.$ of this rock is distinct from surrounding sedimentary rocks, while it can be compared with $\mathrm{C}-\mathrm{O}$ isotope systematics of some carbonatites in the world which probably sourced carbonates from older subduction events. The Sr-Nd isotope composition $\left({ }^{87} \mathrm{Sr}^{86} \mathrm{Sr}_{30} \sim 0.7062 ;{ }^{143} \mathrm{Nd} /{ }^{144} \mathrm{Nd}_{30} \sim 0.51205\right)$ points to an enriched reservoir without known counterparts among alkaline rocks from the Eger Rift, perhaps a lithospheric mantle modified in course of the Variscan subduction. The position of the R2 silicocarbonatite in the Sr-Nd space may indicate a continuum of enriched radiogenic isotope systematics in worldwide carbonatite occurrences.

Keywords: carbonatite, České Středohoři Volcanic Complex, Roztoky Intrusive Complex, geochemistry, Sr-Nd-Pb-C-O isotopes Received: 7 January, 2017; accepted: 5 May, 2017; handling editor: E. Jelinek

\section{Introduction}

Intraplate silicate alkaline magmatism commonly involves carbonatites of various types (e.g., Le Bas 1977; Wooley and Kjarsgaard 2008; Chen and Simonetti 2013; Stoppa and Schiazza 2013; Ackerman et al. 2017), although the nature of this relationship remains elusive. Extensive alkaline magmatism was associated with Cenozoic extension in Central and Western Europe (Wimmenauer 1974; Wilson and Downes 2006; Lustrino and Wilson 2007), including the Ohře/Eger Rift in the Bohemian Massif during the Oligocene and Miocene (e.g., Cajz et al. 1999, 2009; Holub et al. 2010; Ulrych et al. 2011).

Whereas carbonatites were documented in association with Cenozoic alkaline complexes in Western Europe (Kaiserstuhl, Delitzsch, Hegau, Laacher See, Auf Dickel, Chabrieres, Calatrava; Wooley and Kjarsgaard 2008), evidence for carbonatites in the Bohemian Massif has been only indirect so far. For example, Kopecký (1987-88) reported on the presence of fenites and the involvement of carbonatite-related metasomatism was proposed for the alkaline intrusive centre in the Doupovské hory Volcanic Complex (Holub et al. 2010). Abundant carbonates of presumably magmatic origin were also described from Late Cretaceous to Early Paleogene alkaline ultramafic lamprophyres (Ulrych et al. 1993, 2014), and magmatic dolomite occurs in the alkaline dyke from the Ralsko Hill, NE Bohemia (Ulrych et al. 1997). Primary carbonate in a metasomatized harzburgite xenolith was described by Frýda and Vokurka (1995) from the České Středohoří Volcanic Complex.

Here, we report on the presence of a silicocarbonatite dyke in the Roztoky Intrusive Complex, the axial and chemically most evolved part of the České Středohoří Volcanic Complex. The silicocarbonatite was drilled by the R-2 borehole (probably in 1968) but the core has never been documented in detail. Petrographic, mineralogical, geochemical, and isotope analyses of the newly discovered dyke are provided, opening questions on the genesis of this unusual rock and its relation to the evolution of mantle-derived intra-plate alkaline magmas.

\section{Geological setting}

Two large alkaline volcanic complexes are located in the SW-NE trending Ohře/Eger Rift: the České Středohoří Volcanic Complex (CSVC) in the northeast (Ulrych et al. 2002) and the Doupovské hory Volcanic Complex (DHVC) in the southwest (Holub et al. 2010). Both units have a central evolved alkaline intrusion: (a) Roztoky Intrusive Complex (RIC) in the centre of the CSVC, well exposed due to deep erosion of the Labe (Elbe) River 

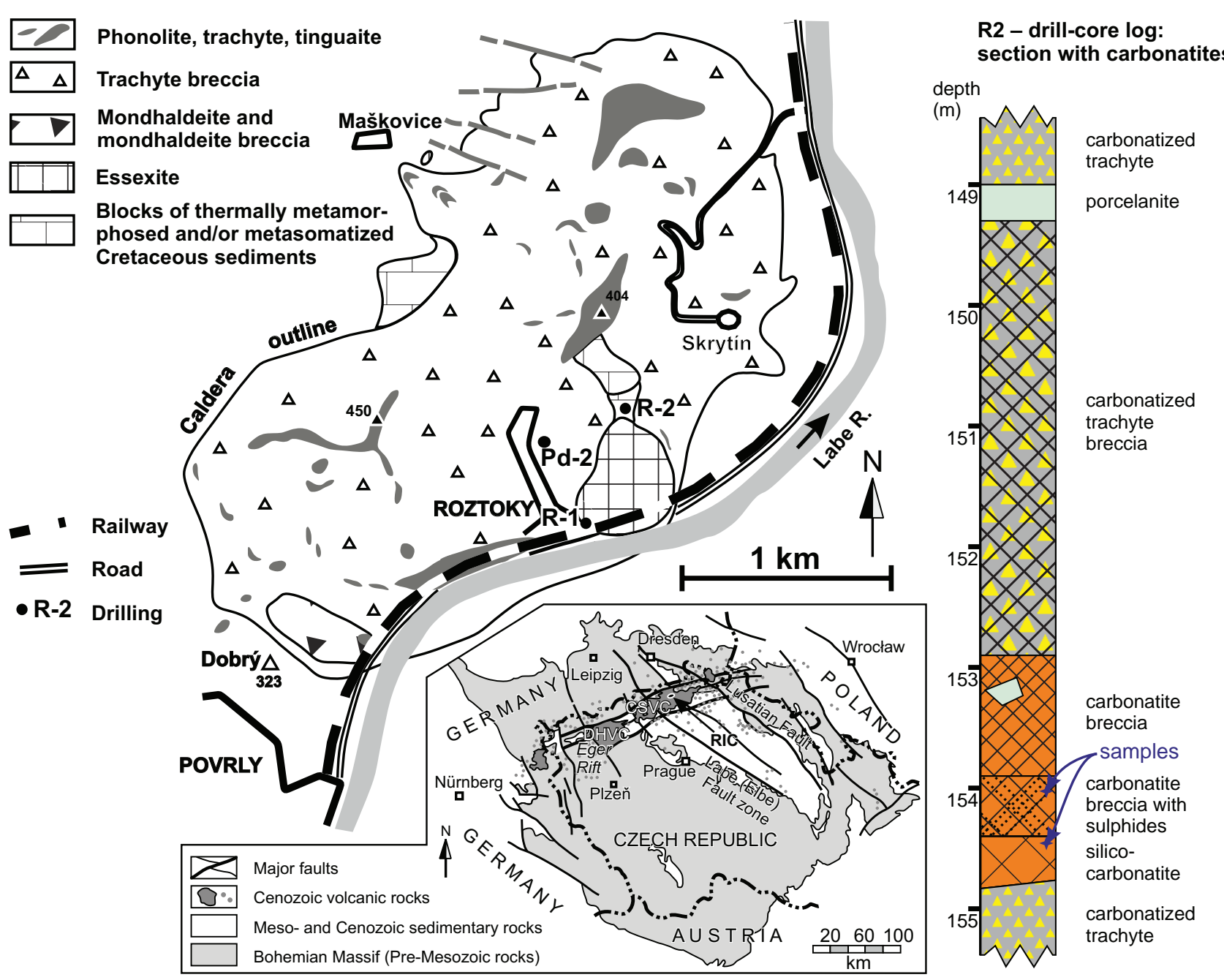

Fig. 1 Sketch map of the Roztoky Intrusive Complex (RIC) with location and core log of the R2 drilling (after Kopecký 1987-88, 2010). Position of the RIC within the České Středohoři Volcanic Complex is shown in the inset: CSVC - České Středohoři Volcanic Complex, DHVC - Doupovské hory Volcanic Complex.

(Ulrych et al. 1983; Ulrych 1998; Ulrych and Balogh 2000; Skála et al. 2014), and (b) the Doupov Intrusive Complex (DIC) in the centre of DHVC, with only the apical part exposed due to limited erosion (Haloda et al. 2010; Holub et al. 2010). The Loučná-Oberwiesenthal Intrusive Centre located on the Krušné hory/Erzgebirge shoulder of the Ohře/Eger Rift lacks the accompanying extrusive alkaline rocks (Ulrych et al. 2005).

The Roztoky Intrusive Complex (Fig. 1) is considered the main feeding and intrusive centre of the CSVC. Evolution of the CSVC lasted from the Late Eocene until the Late Miocene and its eruptive products represent a sequence of four formations: (Cajz et al. 1999, 2009; Ulrych et al. 2002): basanitic Ústí Fm. (36.1-25.5 Ma), trachybasaltic Děčín Fm. (30.8-24.7 Ma), basanitic Dobrná Fm. (24.0-19.3 Ma), and basanitic Štrbice Fm. (13.9-9.0 Ma). The rocks of the RIC (33.1-25.6 Ma, bulk-rocks, K-Ar; Ulrych and Balogh 2000; Ulrych et al. 2011) most likely are intrusive counterparts of the trachybasaltic Děčín Fm.
The RIC was emplaced into an elliptical $(3 \times 1.5 \mathrm{~km})$, SW-NE elongated caldera filled with trachytic breccia and also intruded wider surroundings, up to $5 \mathrm{~km}$ from the central caldera (Skála et al. 2014). The trachytic breccia in the caldera fill is penetrated by numerous trachytic, phonolitic and tinguaitic dykes and plugs (Fig. 1). Hypabyssal intrusions of monzodiorite, essexite, sodalite syenite as well as a radial dike swarm of lamprophyres and felsic differentiates occur in a close proximity to the centre (Ulrych et al. 1983; Jelínek et al. 1989; Ulrych 1998). The geometry of the essexite and monzodiorite intrusions was reconstructed on the basis of a geophysical survey (Mrlina and Cajz 2006) which suggested the existence of a single deep body with several protrusions closer to the surface. The monzodiorite intrusion at Roztoky is cross-cut by hydrothermal carbonate veins with $\mathrm{Pb}-\mathrm{Zn}-\mathrm{Cu}(-\mathrm{Ag}-\mathrm{Te}$ ) mineralization (Pivec et al. 1998).

The drilling R2 was located in the central part of the RIC and started in large xenoliths of metamorphosed and 
metasomatized Cretaceous sediments (Kopecký 2010) forming the roof of the intrusion. Deeper, the drilling reached carbonatized trachytes and trachytic breccias penetrated by a dyke of a silicocarbonatite at the depth of $152.9-154.8 \mathrm{~m}$.

\section{Methods}

Two samples were collected from the R2 drill-core. The R2/154.0 sample represents the carbonatite breccia with pyrite-rich dykelets (depth 152.9-154.35 m). The R2/154.4 sample constitutes an apparently coherent silicocarbonatite (depth 154.35-154.8 m). Both samples were thin-sectioned, studied under petrographical microscope and analysed with an electron microprobe. The $\mathrm{X}$-ray diffraction, bulk-rock major element, trace element and $\mathrm{Sr}-\mathrm{Nd}-\mathrm{Pb}-\mathrm{C}-\mathrm{O}$ isotope analyses were obtained on sample R2/154.4. All analytical procedures were carried out at the Czech Geological Survey. Analytical data were processed using the GCDkit software (Janoušek et al. 2006).

\subsection{X-ray diffraction}

The powder X-ray diffraction analysis was performed to identify the mineral phases. The raw data were collected in a conventional Bragg-Brentano geometry on the Bruker D8 Advance diffractometer equipped with Lynx Eye XE detector. The $\mathrm{Cu} K_{\alpha}$ radiation was used. To minimize the background, the sample was placed on a flat low-background silicon wafer. Data were acquired in the angular range $4-80^{\circ} 2 \Theta$, with a step interval of $0.015^{\circ}$. Automatic divergence slit (ADS $10 \mathrm{~mm}$ ) was used. The quantitative phase analysis of the sample was performed using the Rietveld method (Young 2000) in the Topas program (Bruker 2014). The structure models used in the refinement were as follows: calcite (Markgraf and Reeder 1985), quartz (Le Page and Donnay 1976), dolomite (Reeder and Dollase 1989), albite (Ferguson et al. 1958), kaolinite (Bish and Von Dreele 1989), pyrite (Finklea et al. 1976) and phlogopite (Rayner 1974). The March-Dollase correction for the preferred orientation was applied; the [001] direction was used for phlogopite, kaolinite and albite, and the [104] direction for calcite and Fe-bearing dolomite.

\subsection{Whole-rock major and trace element chemistry}

The major element contents were determined by the conventional wet analysis, following the methodology described in Dempírová et al. (2010). The sample was dissolved in the first step using $\mathrm{HF}+\mathrm{HNO}_{3}+\mathrm{H}_{2} \mathrm{SO}_{4}$ at
$220{ }^{\circ} \mathrm{C}$ (determination of $\mathrm{SiO}_{2}$ ), and in the second step in a $\mathrm{HCl}+\mathrm{H}_{2} \mathrm{SO}_{4}$ mixture (remaining oxides). Trace element concentrations were acquired for the bulk sample, leached carbonate fraction (sample treated by cold 2.5M HCl for 10 minutes in an ultrasonic bath) and a non-carbonate residue using an Agilent 7900x ICP-MS. Reference rocks BHVO-2, COQ-1 and JSy-1 were analyzed together with unknown samples. Their values were consistent with published data to within $\pm 10 \%$ for most elements (Jochum et al. 2005).

\subsection{Mineral chemistry and X-ray elemental mapping}

The quantitative chemical analyses of individual mineral phases were conducted on a Tescan MIRA 3GMU electron microprobe fitted with SDD X-Max $80 \mathrm{~mm}^{2}$ EDS detector and AZtecEnergy software (Oxford Instruments). Point analyses, and the area analyses of selected minerals and parts of the sample were acquired individually, using the following conditions: accelerating voltage $15 \mathrm{kV}$, working distance $15 \mathrm{~mm}, 3 \mathrm{nA}$ probe current, $30 \mathrm{~s}$ acquisition time. Mineral set of standards (SPI) was used for standardization. Representative proportions of MgO, $\mathrm{CaO}$ and $\mathrm{FeO}$ were integrated from X-ray elemental maps with $0.5 \mu \mathrm{m}$ step.

\subsection{Radiogenic isotopes $(\mathrm{Sr}-\mathrm{Nd}-\mathrm{Pb})$}

For $\mathrm{Sr}-\mathrm{Nd}-\mathrm{Pb}$ isotope analysis, two aliquots of the powdered sample ( $\sim .5 \mathrm{~g}$ each) were leached in $40 \mathrm{ml}$ of $2.5 \mathrm{~N} \mathrm{HCl}$ for $10 \mathrm{~min}$ in ultrasonic bath to dissolve the carbonate phase. Residual silicate phases were removed by centrifugation and dissolved in the mixture of concentrated $\mathrm{HF}$ and $\mathrm{HNO}_{3}$. The final solution of the bulk-rock sample was then recombined from the dissolved carbonate and silicate portions; carbonate and silicate fractions from the second aliquot were treated separately.

Cation-exchange column chemistry (BioRad AG50W$\mathrm{X} 8,200-400$ mesh) was employed to isolate $\mathrm{Sr}$ from the REE fraction. Strontium and $\mathrm{Pb}$ fractions were then cleaned using Sr.spec resin whereas Nd was isolated from the other REE using Ln.spec resin (Pin et al. 2014).

The Sr-Nd isotope compositions were analysed using Thermo Fisher Neptune MC-ICPMS. The external precision was established by repeat measurements of the international reference standards [NBS987: ${ }^{87} \mathrm{Sr} /{ }^{86} \mathrm{Sr}$ $=0.710300 \pm 46(2 \sigma, \mathrm{n}=48) ; \mathrm{JNdi}-1:{ }^{143} \mathrm{Nd} /{ }^{144} \mathrm{Nd}=$ $0.512081 \pm 14(2 \sigma, \mathrm{n}=32)]$; results were re-normalized to ${ }^{87} \mathrm{Sr} /{ }^{66} \mathrm{Sr}=0.71024$ and ${ }^{143} \mathrm{Nd} /{ }^{144} \mathrm{Nd}=0.512115$ (Jochum et al. 2005). The Nd isotope compositions were verified using a Thermo Fisher Triton Plus thermal ionization mass spectrometer in static mode; identical mass bias 
correction as above $\left(\mathrm{JNdi}-1:{ }^{143} \mathrm{Nd} /{ }^{144} \mathrm{Nd}=0.512099 \pm 6\right.$; $2 \sigma, \mathrm{n}=19$ ) was applied.

The initial Sr-Nd ratios were calculated using the following decay constants: $\lambda_{87 \mathrm{Rb}}=1.42 \times 10^{-11} \mathrm{y}^{-1}$ (Steiger and Jäger 1977) and $\lambda_{147 \mathrm{sm}}=6.54 \times 10^{-12} \mathrm{y}^{-1}$ (Lugmair and Marti 1978). The $\varepsilon_{\mathrm{Nd}}$ values were calculated using ${ }^{147} \mathrm{Sm} /{ }^{144} \mathrm{Nd}_{\text {CHUR }}=0.1967$ and ${ }^{143} \mathrm{Nd} /{ }^{144} \mathrm{Nd}_{\text {CHUR }}=0.512638$ (Jacobsen and Wasserburg 1980; CHUR: Chondritic Uniform Reservoir).

Lead was separated using Sr.spec resin and $\mathrm{Pb}$ fraction was collected with $6 \mathrm{M} \mathrm{HCl}$. Samples were diluted with $2 \% \mathrm{HNO}_{3}$ and spiked with the NIST SRM $997 \mathrm{Tl}$ ( 20 $\mathrm{ppb} \mathrm{Tl}$ at $100 \mathrm{ppb} \mathrm{Pb}$ ). Isotope analyses were made with a Neptune MC-ICPMS. Total procedural blanks were $\sim 66$ pg Nd and $\sim 25$ pg Pb.

\subsection{Stable isotopes (C-O)}

Selective leaching of a bulk sample of R2 silicocarbonatite was applied to acquire $\delta^{13} \mathrm{C}$ and $\delta^{18} \mathrm{O}$ values for the carbonate fraction following the methodology of McCrea (1950). In brief, $\mathrm{H}_{3} \mathrm{PO}_{4}$ with $\mathrm{K}_{2} \mathrm{Cr}_{2} \mathrm{O}_{7}$ was administered to the sample powder, and reacted at room temperature under vacuum for 24 hours (calcite) and 72 hours (dolomite). The measurements were performed using a dual inlet Delta V Advantage mass spectrometer (Thermo Fisher). The results for $\mathrm{C}$ and $\mathrm{O}$ are presented relative to V-PDB and V-SMOW reference materials, respectively, with the total analytical error of $<0.1 \%$ o $(2 \sigma)$. Due to different acid fractionation factors for calcite and dolomite, the $\delta^{18} \mathrm{O}$ value for dolomite was corrected by $-0.84 \%$ (Becker and Clayton 1976; Kim et al. 2015).

\section{Results}

\subsection{Petrography}

The silicocarbonatite dyke with the total thickness of $1.9 \mathrm{~m}$ in the drill section has two macroscopically distinct facies: (i) a brecciated upper section, and (ii) a macroscopically homogeneous lower section.

The upper section (152.9-154.35 m; sample $\mathrm{R} 2 / 154.0 \mathrm{~m}$ ) is characterised by a macroscopically visible brecciated texture. The breccia consists of angular jig-saw-fitting fragments of a whitish to yellowish carbonate-rich rock healed by another generation of a similar rock. In its lower part (153.9-154.35 m) this facies contains frequent $1-5 \mathrm{~mm}$ thick darker bands (Fig. 2a) with abundant aggregates of radially arranged fibre-shaped magnetite, possibly replacing the original pyrite. The set of bands is displaced by frequent subvertical fractures (Fig. 2a). The conspicuously brecciated part of the silicocarbonatite dyke also contains frequent late open cracks filled with hydrothermal calcite and dolomite.

The lower facies (154.35-154.8 m; sample R2/154.4 $\mathrm{m}$ ) is light in colour and appears macroscopically homogeneous. However, inhomogeneous texture becomes apparent at the thin-section scale (Fig. 2b-c). Three different sub-facies were distinguished, based on variations in mineral proportions, geometry and textures: (1) the dolomite-rich (D-type), (2) the silicate-rich (S-type) and (3) the pyrite-rich (P-type). The characteristic features of all three types are summarized in Tab. 1. This facies does not contain any open cracks or joints filled with idiomorphic crystals resulting from hydrothermal precipitation (Chakhmouradian et al. 2016), or any heterogenic fragments (alkaline rocks or xenoliths), all of which would indicate explosive, or kinetic brecciating of solidified rock.

The dolomite-rich (D-type) silicocarbonatite forms angular fragments $1-3 \mathrm{~mm}$ in diameter. Among the dolomite-rich silico-carbonate fragments, two different varieties can be distinguished (D1 and D2, Fig. 2b-c). The $D 1$ variety is silicate-poor (up to 10 vol. \% silicate phases) with accessory pyrite. The individual crystals of carbonates reach up to $0.2 \mathrm{~mm}$ in diameter, but their boundaries are irregular and rugged. The carbonates contain frequent dispersed inclusions of K-feldspar, oligoclase $\left(\mathrm{An}_{16}-\mathrm{An}_{28}\right)$, diopside, phlogopite, fluorapatite, quartz, titanite, rutile, celestine, Ba-celestine and gypsum (Fig. 2d). The surrounding silicates (quartz, oligoclase and kaolinized K-feldspar) are skeletally intergrowing with carbonates. The D2 variety is more silicate-rich (30-40 vol. \% silicate phases) and finer grained (Fig. 2c) with intimate intergrowths of silicates (quartz, albite $\mathrm{An}_{06}$, kaolinized K-feldspar) with carbonates. The carbonates form larger crystals (up to $0.05 \mathrm{~mm}$ ) compared to silicates $(<0.02 \mathrm{~mm})$.

The D-type fragments are enclosed in a network of silicate-rich (S-type) silicocarbonatite dykelets $\sim 0.2-0.5$ $\mathrm{mm}$ thick (Fig. 2b-c). The S-type is characterised by larger amounts of silicates (up to 55 vol. \%); it is very fine-grained with intimate intergrowths of silicates and carbonates (Fig. 3), where none of the minerals has automorphic crystal shapes.

Locally, isolated, up to $1.5 \mathrm{~mm}$ wide dykelets of coarser-grained pyrite-bearing silicocarbonatite (P-type) occur (Figs 2e-f, 3). Idiomorphic phenocrysts of pyrite ( 5 vol. \%; up to $0.15 \mathrm{~mm}$ ) are enclosed in an aggregate dominated by relatively coarse-grained carbonate (individual crystals up to $0.4 \mathrm{~mm}$ ) with variable amounts of silicates (up to 50 vol. \%). Even these large carbonate crystals intergrowing with surrounding silicates have irregular rugged boundaries. The pyrite phenocrysts contain apatite inclusions, and the surrounding carbonate encloses microcrysts of zircon and rutile. 

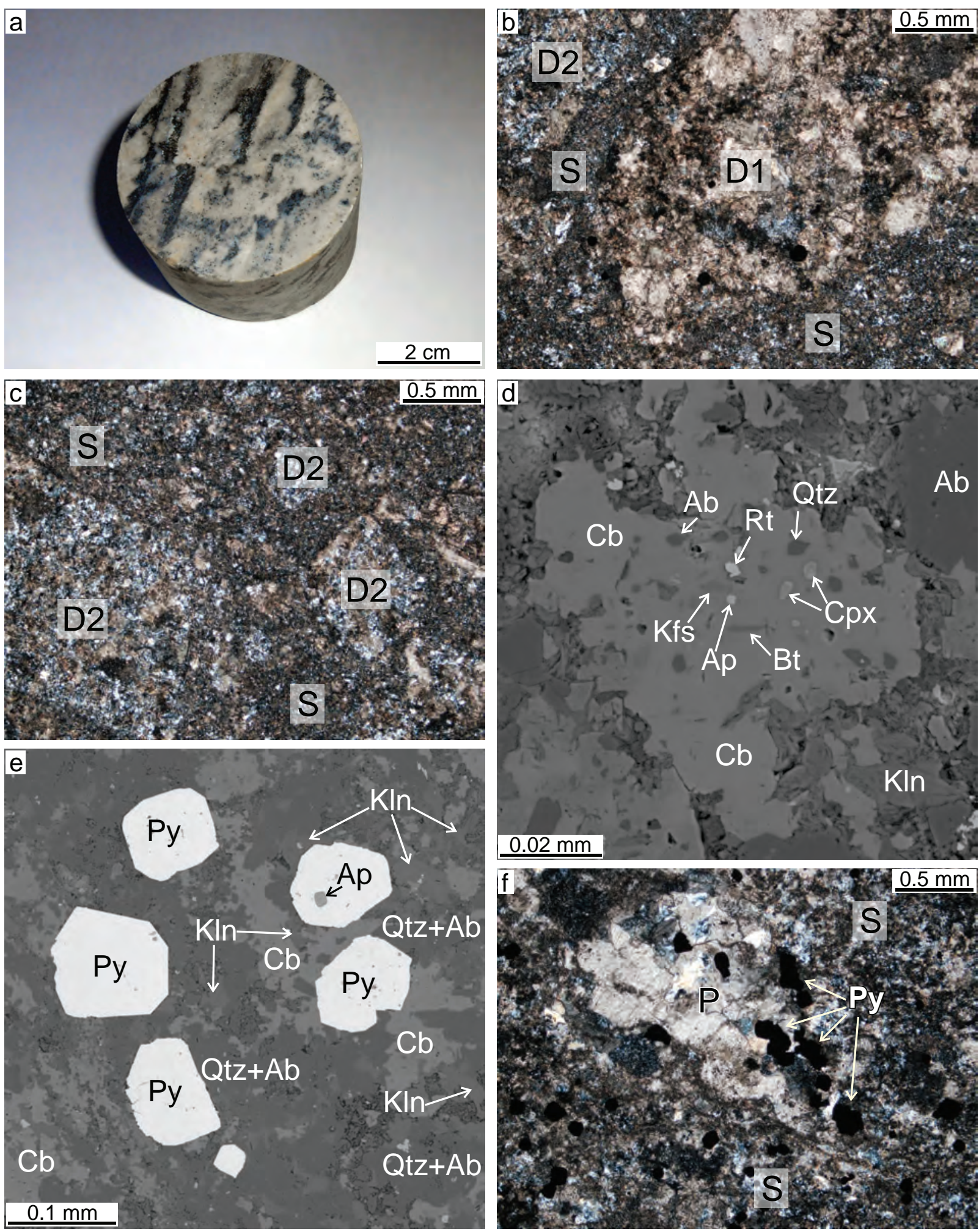

Fig. 2 Petrography of the silicocarbonatite dyke in R2 drilling: a - Drill-core sample of the magnetite-rich breccia atop the silicocarbonatite: depth $154.0 \mathrm{~m}$; b - Fragments of dolomite-rich silicocarbonatite (D1 and D2) annealed by the silicate-rich silicocarbonatite (S): depth $154.4 \mathrm{~m}$, cross-polarized light (XPL); c - Fragments of D2 type silicocarbonatite annealed by the S-type silicocarbonatite: depth $154.4 \mathrm{~m}$, XPL; d - Back-scattered electron image of carbonate (calcite) domain in the D1 type silicocarbonatite surrounded by albite (Ab), kaolinite (Kln) and quartz, and enclosing inclusions of apatite (Ap), albite, biotite (Bt), clinopyroxene (Cpx), K-feldspar ( Kfs), quartz (Qtz) and rutile (Rt); e - Back-scattered electron image of pyrite (py)-rich silicocarbonatite $(\mathrm{P}), \mathrm{Cb}=$ carbonate; $\mathbf{f}-$ Pocket of pyrite-rich silicocarbonatite $(\mathrm{P})$ surrounded by $\mathrm{S}$ type silicocarbonatite: depth $154.4 \mathrm{~m}$, XPL. 

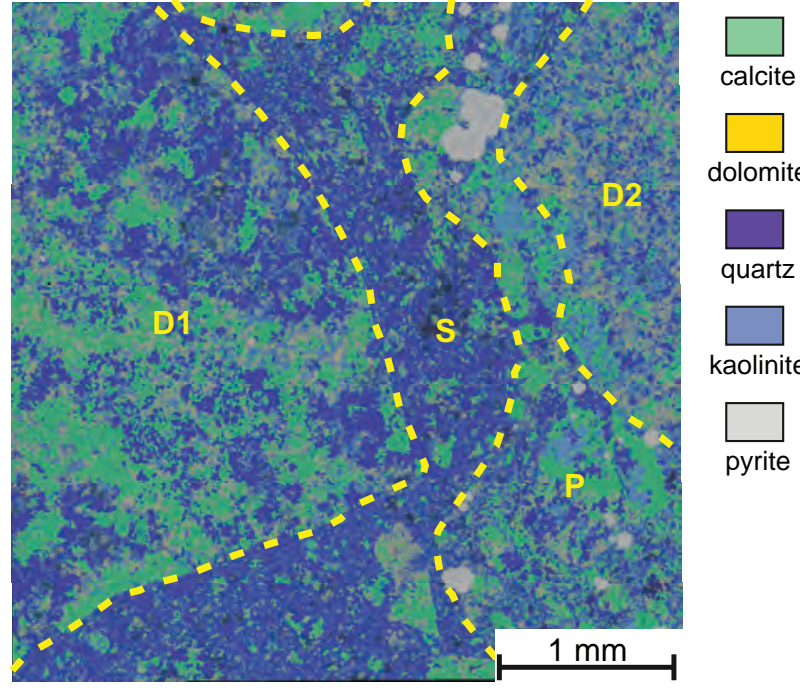

Fig. 3 Areal mapping scan of the sample R2/154.4 showing variabilities in texture and mineral proportions among defined types (see also Tab. 1): D1 - dolomite-rich variety with less silicates, D2 - dolomite-rich variety with more silicates, $\mathrm{S}$ - silicates-rich, $\mathrm{P}$ - pyrite bearing.

The carbonates in all described types consist of mixtures of calcite and Fe-bearing dolomite (Tab. 1; Fig. 3). The small domains $(\sim 20 \mu \mathrm{m})$ of dolomite are randomly distributed throughout the prevailing calcite. The shape of such domains is irregular and diffuse (Fig. 3), not respecting any crystal structure (oscillatory zoning of growing crystal, immiscibility lamellae, etc.).

The textures of D-, S- and P-type silicocarbonatites with intimate intergrowths of silicates and carbonates and dispersed diffused micrometre-scale domains of dolomite in calcite stands in contrast with the structure of idiomorphic carbonate crystals with well-defined growth zones observed in late hydrothermal veins filling the open cracks in the breccia facies.

\subsection{Mineralogy}

The quantitative XRD phase analysis (calcite, quartz, Febearing dolomite, albite, kaolinite, pyrite and phlogopite) confirmed the petrographical observations showing that the studied dyke is dominated by calcite (54.6 wt. \%) and Fe-bearing dolomite (20.1 wt. \%). The predominant silicate phases are quartz (10.0 wt. \%), sodic plagioclase (9.8 wt. \%), kaolinite (2.5 wt. \%), phlogopite (2.5 wt. \%), and pyrite (0.5 wt. \%).

The bimodal chemical composition of carbonates was detected by microprobe analysis. Calcite has uniform composition with a low proportion of magnesite, rhodochrosite and siderite admixtures (in total $<6.2 \mathrm{~mol} \%$; Fig. 4). Dolomite displays a wider compositional range with the sum of rhodochrosite and siderite proportions varying between 11 and 16 mol. \% (Fig. 4). The composition of sodic plagioclase varies from oligoclase to albite $\left(A n_{06}\right.$ to $\left.A n_{28}\right)$, but the chemistry of K-feldspar could not be constrained due to kaolinization. Several grains of intact K-feldspar were found only as inclusions in carbonates or in the upper brecciated part, where the fluids could escape rapidly without altering the cooling rock. The mafic minerals are represented by $\mathrm{Mg}$-rich members such as diopside $(\mathrm{Mg}=0.7-0.8$ apfu; $\mathrm{Ca}=0.97-1 \mathrm{apfu})$, and phlogopite $(\mathrm{Mg}=2.35 \mathrm{apfu})$. Accessory $\mathrm{Ba}-\mathrm{Sr}$ sulphates (barite-celestine) with up to 15 wt. \% $\mathrm{BaO}$ were found in carbonates.

\subsection{Bulk-rock geochemistry}

Major and trace elements were determined in a bulkrock sample. In parallel, trace element analysis was also performed for the acid-leached carbonate fraction (hereafter referred to as $\mathrm{CF}$ ) and the non-carbonate residuum (NCF). The results of the analyses are listed in Tabs 2 and 3. The bulk rock contains 22.8 wt. $\% \mathrm{SiO}_{2}$ and 7.6 wt. \% $\mathrm{Al}_{2} \mathrm{O}_{3}$ with rather low concentrations of alkalis $\left(\mathrm{Na}_{2} \mathrm{O}+\right.$ $\mathrm{K}_{2} \mathrm{O}=2.5$ wt. \%). In the Hamilton's diagram (Hamilton et al. 1979) the rock plots on the carbonate/silicate liquid field boundary (Fig. 5).

Most elements are carried by the carbonate fraction, except the alkalis ( $\mathrm{Li}, \mathrm{Rb}, \mathrm{Cs}$ ), Th, U and high-fieldstrength elements (HFSE: Zr, Hf, Nb, Ta) (Fig. 6a). In particular, HFSE show extreme depletions in the CF. The low $\mathrm{REE}$ content $(\Sigma \mathrm{REE}=82.6 \mathrm{ppm}$ in bulk sample $)$ is

Tab. 1 Petrological characteristics of three types of silicocarbonatites, and inferred temperatures of carbonate magma crystallization (calculated according to Rice 1977)

\begin{tabular}{lccc}
\hline & D-type & P-type & S-type \\
\hline Characteristics & Dolomite-rich & Pyrite-bearing & Silicate-rich \\
Form & Clasts & Isolated dykelets & Branched dykelets \\
Silicates (vol.\%) & D1: $<10(\mathrm{D} 1)$ & $<50$ & $52-55$ \\
Dolomite (\% of carbonates) & D2: $30-40$ & 33.5 & 38.0 \\
Pyrite (vol. \%) & 28.0 & $3-5$ & Absent \\
Mg\# & Traces & 61 & 47 \\
Ca\# & 62 & 80 & 80 \\
$\mathrm{~T}_{\text {Rice }}\left({ }^{\circ} \mathrm{C}\right)$ & 84 & $720-800$ & $660-800$ \\
\hline
\end{tabular}


Fig. 4 Composition of carbonates in the studied rock (in molar proportions).

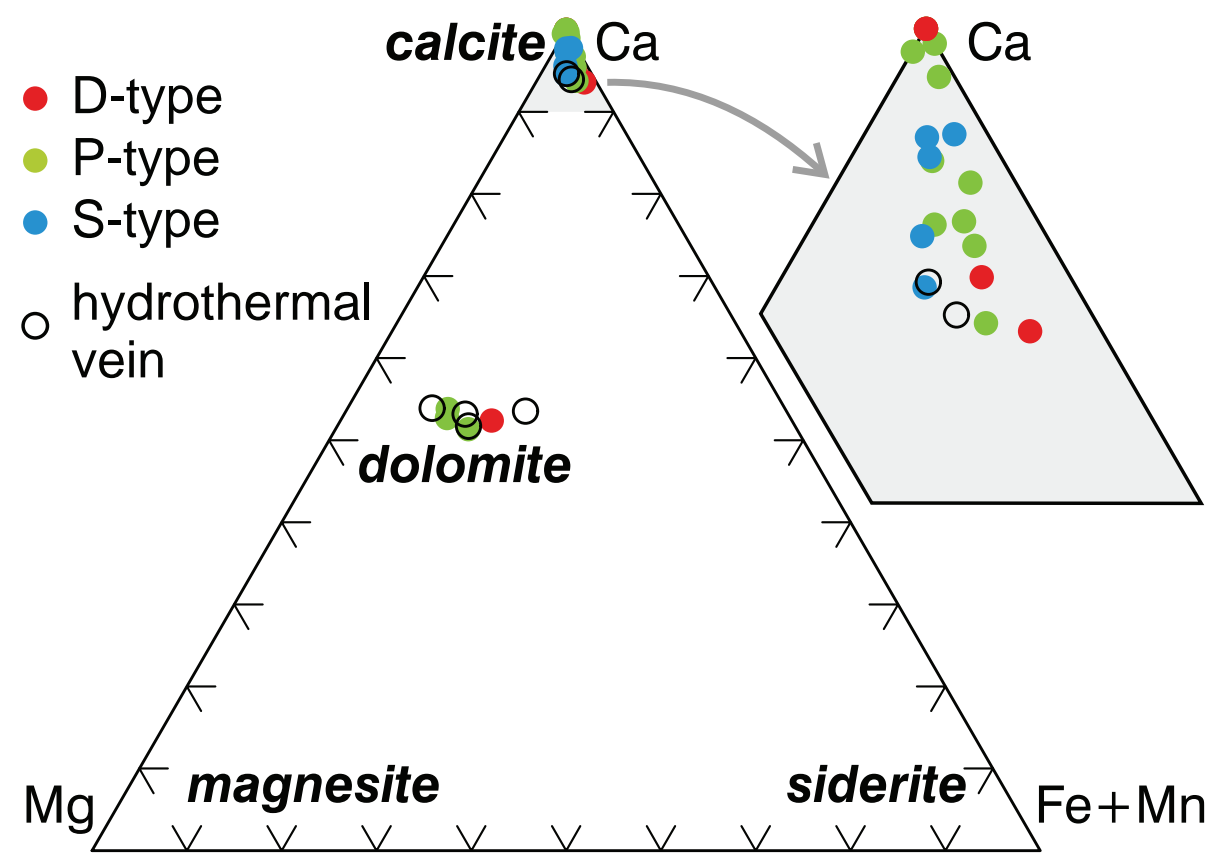

dominated by the CF $(\Sigma \mathrm{REE}=208 \mathrm{ppm})$, whereas the NCF has only 17 ppm REE. The chondrite-normalized (Anders and Grevesse 1989) REE patterns are plotted in Fig. 6b. All three sub-samples show subparallel LREE segments $\left(\mathrm{La}_{\mathrm{N}} / \mathrm{Sm}_{\mathrm{N}}=3.9-4.1\right)$ but the degree of LREE/ HREE fractionation differs for bulk sample and carbonate $\left(\mathrm{La}_{\mathrm{N}} / \mathrm{Yb}_{\mathrm{N}}\right.$ of 11.5 and 14.2, respectively) versus noncarbonate fraction $\left(\mathrm{La}_{\mathrm{N}} / \mathrm{Yb}_{\mathrm{N}}=3.3\right)$, likely as a result of somewhat decreased middle REE (Sm-Gd) concentra-

Tab. 2 Major-element composition of whole-rock sample R2/154.4 m (wt. \%)

\begin{tabular}{lc}
\hline wt. \% & $\mathrm{R} 2 / 154.4 \mathrm{~m}$ \\
\hline $\mathrm{SiO}_{2}$ & 22.82 \\
$\mathrm{TiO}_{2}$ & 0.29 \\
$\mathrm{Al}_{2} \mathrm{O}_{3}$ & 7.56 \\
$\mathrm{Fe}_{2} \mathrm{O}_{3}$ & 0.52 \\
$\mathrm{FeO}$ & 2.32 \\
$\mathrm{MnO}$ & 0.099 \\
$\mathrm{MgO}$ & 2.74 \\
$\mathrm{CaO}$ & 31.54 \\
$\mathrm{Na}_{2} \mathrm{O}$ & 0.92 \\
$\mathrm{~K}_{2} \mathrm{O}$ & 1.58 \\
$\mathrm{P}_{2} \mathrm{O}_{5}$ & 0.092 \\
$\mathrm{H}_{2} \mathrm{O}^{+}$ & 0.79 \\
$\mathrm{H}_{2} \mathrm{O}^{-}$ & 0.39 \\
$\mathrm{CO}_{2}$ & 27.02 \\
$\mathrm{~F}$ & 0.125 \\
$\mathrm{~S}$ & 0.765 \\
$\mathrm{Mg \#}$ & 67.8 \\
$\mathrm{Ca} \#$ & 0.84 \\
\hline Total & 99.58 \\
\hline
\end{tabular}

$\mathrm{Mg} \#-$ molar $\mathrm{MgO} /\left(\mathrm{MgO}+\mathrm{FeO}_{\text {tot }}\right)$

$\mathrm{Ca} \#$ - molar $\mathrm{Ca} /(\mathrm{Ca}+\mathrm{Fe}+\mathrm{Mg})$ tions in the NCF (Fig. 6b). The moderate depletion in $\mathrm{Eu}$ is apparent for all aliquots $\left(\mathrm{Eu} / \mathrm{Eu}^{*}=0.71-0.78\right)$.

The distribution of incompatible trace elements between CF and NCF observed in this study (Fig. 6) is not a general feature of all carbonatites. For example, the complementary behaviour of HFSE in carbonate and non-carbonate fractions such as found in this study, i.e. troughs in carbonates and enrichments in non-carbonate fractions, is similar to that reported for some carbonatites from Uganda and Malawi (Bizimis et al. 2003) as well as to experimental results (e.g., Veksler et al. 1998). On the other hand, some other carbonatites analysed by Bizimis et al. (2003) showed no HFSE fractionation between the carbonate and non-carbonate fractions. This implies that carbonate fraction is not always devoid of HFSE, as also indicated by experimental investigations and natural observations (Martin et al. 2012). Interestingly, REE in the R2 sample from the current study are preferentially incorporated into carbonate, which may have important implications for the unmixing history of the carbonatitesilicate melt system. The results of Veksler et al. (1998 and discussion therein) showed some dependence of partitioning on pressure, temperature and chemistry; preferential partitioning of REE into carbonate over silicate melt could indicate greater depths for the immiscibility to occur. However, only a future in situ analytical work may provide further constraints on the petrogenesis of the R2 silicocarbonatite.

\subsection{Radiogenic and stable isotope systematics}

The results of radiogenic and stable isotope measurements of the R2 silicocarbonatite are listed in Tab. 4. Strontium 
Tab. 3 Trace-element composition of whole-rock, carbonate (CF) and non-carbonate (NCF) fractions and data obtained for international standards (ppm)

\begin{tabular}{|c|c|c|c|c|c|c|}
\hline & Bulk & $\mathrm{CF}$ & NCF & BHVO-2 & COQ-1 & JSy-1 \\
\hline $\mathrm{Li}$ & 2.92 & 0.89 & 8.06 & 4.50 & 3.83 & 15.6 \\
\hline Sc & 5.67 & 14.1 & 3.31 & 31.0 & 2.34 & 0.16 \\
\hline $\mathrm{V}$ & 48.4 & 31.4 & 115 & 313 & $<2$ & 21.3 \\
\hline $\mathrm{Cr}$ & 33.1 & 24.4 & 78.4 & 281 & 3.94 & 1.63 \\
\hline Co & 4.37 & 8.72 & 4.52 & 42.2 & 2.87 & 0.02 \\
\hline $\mathrm{Ni}$ & 23.5 & 35.6 & 33.3 & 147 & 0.56 & 0.20 \\
\hline $\mathrm{Cu}$ & 0.31 & $<0.1$ & 1.28 & 123 & $<0.1$ & $<0.1$ \\
\hline $\mathrm{Zn}$ & 27.1 & 57.9 & 26.4 & 103 & 185 & 1.56 \\
\hline $\mathrm{Ga}$ & 8.15 & 2.17 & 22.4 & 20.5 & 24.3 & 21.7 \\
\hline $\mathrm{Rb}$ & 24.8 & 9.81 & 133 & 10.3 & 11.9 & 59.6 \\
\hline $\mathrm{Sr}$ & 336 & 917 & 110 & 376 & 11333 & 18.9 \\
\hline $\mathrm{Y}$ & 10.6 & 28.2 & 4.40 & 25.1 & 82.3 & 2.47 \\
\hline $\mathrm{Zr}$ & 31.4 & 6.47 & 84.5 & 118 & 22.7 & 33.3 \\
\hline $\mathrm{Nb}$ & 5.71 & 0.31 & 16.4 & 19.0 & 4265 & 0.24 \\
\hline $\mathrm{Cd}$ & 0.056 & 0.059 & 0.10 & 0.14 & 0.55 & 0.024 \\
\hline Cs & 1.89 & 1.40 & 4.49 & 0.12 & 0.27 & 0.70 \\
\hline $\mathrm{Ba}$ & 32.0 & 29.6 & 71.5 & 134 & 1095 & 14.9 \\
\hline $\mathrm{La}$ & 17.4 & 44.0 & 3.33 & 15.5 & 826 & 1.62 \\
\hline $\mathrm{Ce}$ & 34.7 & 89.9 & 6.81 & 38.6 & 1860 & 3.31 \\
\hline $\operatorname{Pr}$ & 4.14 & 10.9 & 0.72 & 5.70 & 164 & 0.38 \\
\hline $\mathrm{Nd}$ & 15.0 & 37.1 & 2.54 & 25.2 & 480 & 1.37 \\
\hline $\mathrm{Sm}$ & 2.82 & 6.83 & 0.51 & 6.30 & 59.2 & 0.29 \\
\hline $\mathrm{Eu}$ & 0.63 & 1.56 & 0.14 & 2.15 & 19.5 & 0.15 \\
\hline Gd & 2.58 & 6.47 & 0.54 & 6.35 & 53.4 & 0.30 \\
\hline $\mathrm{Tb}$ & 0.36 & 0.88 & 0.10 & 0.98 & 9.01 & 0.058 \\
\hline Dy & 2.03 & 4.59 & 0.73 & 5.40 & 13.8 & 0.38 \\
\hline Но & 0.41 & 0.92 & 0.19 & 1.05 & 7.45 & 0.095 \\
\hline Er & 1.17 & 2.48 & 0.61 & 2.70 & 12.2 & 0.34 \\
\hline $\mathrm{Tm}$ & 0.16 & 0.35 & 0.10 & 0.35 & 4.67 & 0.057 \\
\hline $\mathrm{Yb}$ & 1.05 & 2.14 & 0.69 & 2.10 & 8.06 & 0.43 \\
\hline $\mathrm{Lu}$ & 0.16 & 0.32 & 0.11 & 0.30 & 4.30 & 0.075 \\
\hline Hf & 1.18 & 0.16 & 3.22 & 5.33 & 0.56 & 0.94 \\
\hline $\mathrm{Ta}$ & 0.39 & 0.01 & 1.17 & 1.77 & 45.6 & 0.12 \\
\hline W & 0.77 & 0.17 & 2.02 & 0.30 & 2.17 & 0.058 \\
\hline $\mathrm{Tl}$ & 0.41 & 0.09 & 1.11 & 0.017 & 0.25 & 0.65 \\
\hline $\mathrm{Pb}$ & 1.58 & 3.63 & 1.30 & 1.58 & 3.84 & 4.83 \\
\hline Th & 4.07 & 7.12 & 6.10 & 3.56 & 1.41 & 0.54 \\
\hline $\mathrm{U}$ & 0.88 & 0.70 & 2.10 & 0.43 & 9.70 & 0.13 \\
\hline $\mathrm{Zr} / \mathrm{Hf}$ & 26.8 & 39.9 & 26.3 & & & \\
\hline $\mathrm{Nb} / \mathrm{Ta}$ & 14.6 & 53.2 & 14.1 & & & \\
\hline $\mathrm{Th} / \mathrm{U}$ & 4.61 & 10.21 & 2.90 & & & \\
\hline $\mathrm{La}_{\mathrm{N}} / \mathrm{Sm}_{\mathrm{N}}$ & 3.87 & 4.04 & 4.10 & & & \\
\hline $\mathrm{La}_{\mathrm{N}} / \mathrm{Yb}_{\mathrm{N}}$ & 11.5 & 14.2 & 3.33 & & & \\
\hline $\mathrm{Eu} / \mathrm{Eu}^{*}$ & 0.71 & 0.71 & 0.78 & & & \\
\hline
\end{tabular}

$\mathrm{Eu} / \mathrm{Eu}^{*}$ is defined as chondrite-normalized $\mathrm{Eu} / \sqrt{ }(\mathrm{Sm} \times \mathrm{Gd})$; normalization values are from Anders and Grevesse (1989)

and Nd data were recast to initial values assuming the intrusion age of $30 \mathrm{Ma}$ (Ulrych and Balogh 2000) and using the ICPMS concentration data. Whereas there is no difference between the carbonate and non-carbonate fractions for ${ }^{143} \mathrm{Nd} /{ }^{144} \mathrm{Nd}_{30}$ outside the analytical uncertainty $\left({ }^{143} \mathrm{Nd} /{ }^{144} \mathrm{Nd}_{30}=0.51205\right.$ for the whole-rock aliquot), the NCF of the R2 silicocarbonatite has slightly more radio- genic Sr isotope signature than $\mathrm{CF}\left({ }^{87} \mathrm{Sr} /{ }^{86} \mathrm{Sr}_{30}=0.70622\right.$ versus 0.70610; Fig. 7), the whole-rock aliquot has ${ }^{87} \mathrm{Sr} /{ }^{86} \mathrm{Sr}_{30}=0.70615$ (Tab. 4).

All three aliquots have similar $\mathrm{Pb}$ isotope compositions (Tab. 4). The $\delta^{18} \mathrm{O}$ and $\delta^{13} \mathrm{C}$ values for CF of the R2 silicocarbonatite are $+7.43 \%$ and $-2.46 \%$, respectively, falling slightly above the currently accepted range of the primary mantle carbonatites $\left(\delta^{18} \mathrm{O}\right.$ $=5-8 \%$ and $\delta^{13} \mathrm{C}=-7$ to $-5 \%$; Ray and Ramesh 2006 and references therein).

\section{Discussion}

\subsection{Texture of the studied rock}

The presence of three types of silicocarbonatite $(\mathrm{D}, \mathrm{S}$ and $\mathrm{P}$; Section 4.1) suggests complex evolution of the Roztoky silicocarbonatite. The texture of all three types indicates several phases of magmatic origin. The annealed texture with the absence of wall-rock fragments (Cretaceous sedimentary xenoliths and alkaline igneous rocks), or open cracks with late mineralization suggests that this rock does not represent breccia (e.g., McPhie et al. 1993; Chakhmouradian et al. 2016). It rather originated from a continuous process of melt injection cooling - kinetic fragmentation - annealing by new portions of melt. Similar textures, albeit with larger grain-size contrasts, were found for carbonatites from Kaiserstuhl (Germany) and Kerimasi (Tanzania), and were interpreted in terms of reincorporated autholiths of a disaggregated carbonatite cumulate (Chakhmouradian et al. 2016). The intimate calcite-dolomite intergrowths document further evolution through sub-solidus immiscibility re-equilibration (Fig. 3) commonly described from carbonatites (e.g., Chakhmouradian et al. 2016). These textural features 
Fig. 5 Bulk-rock major oxide composition (R2/154.4 sample as filled circle) in the Hamilton's projection (Hamilton et al. 1979) illustrating the silicate-carbonate liquid miscibility gap and a possible melting path of a carbonated peridotite (the grey arrow from the area of immiscible carbonatite to alkali basalts to evolved nephelinites), projected from $\mathrm{CO}_{2}$ (after Lee and Wyllie 1997; Tappe et al. 2006). The e-f arrow shows the silicate-carbonate liquidus field boundary (after Lee and Wyllie 1997). The 1.0 GPa solvus is from Lee and Wyllie (1997), and the 1.5 GPa solvus from Brooker (1998). Silicate rocks data from RIC (Skála et al. 2014, open circles) are shown for comparison.

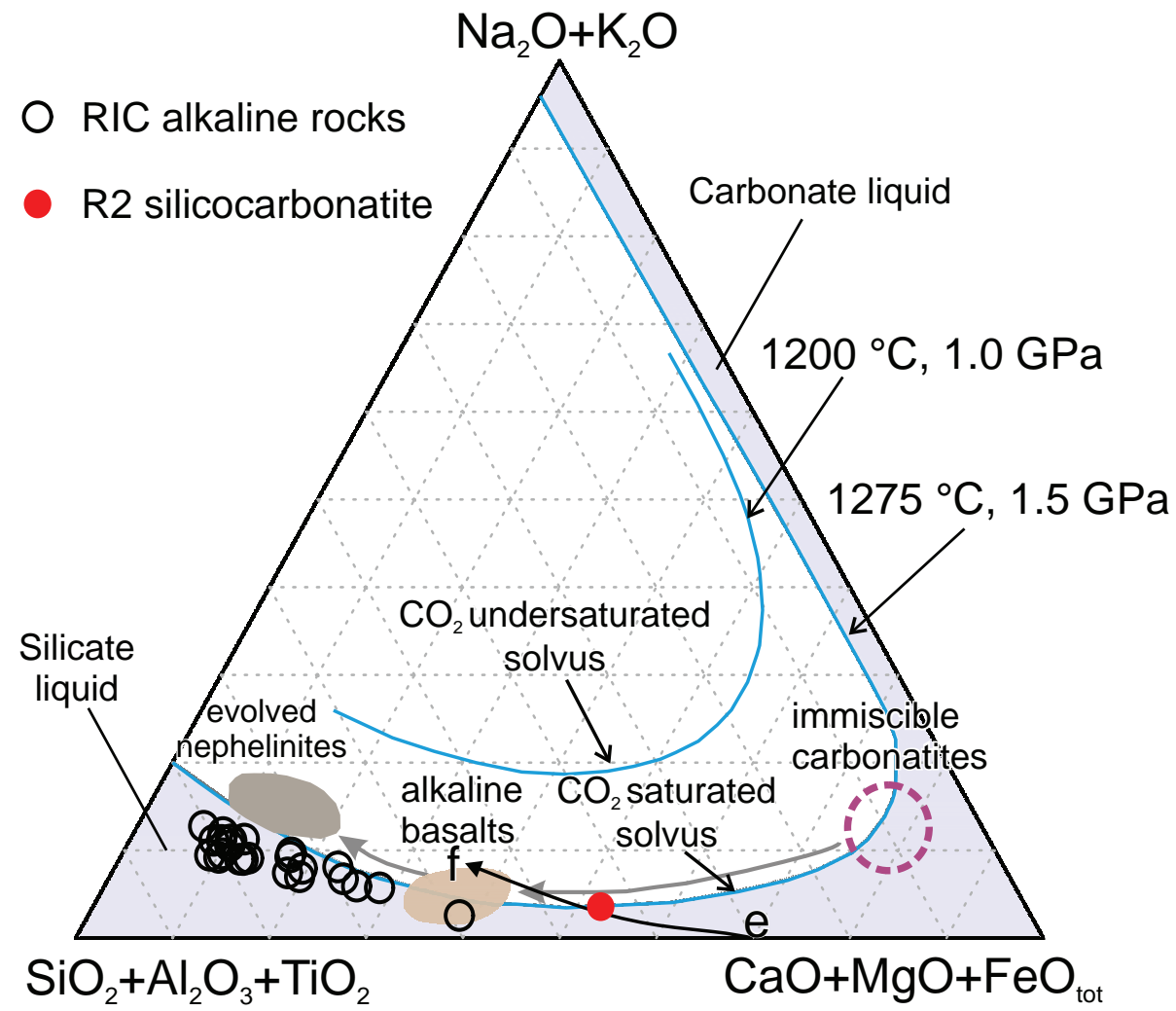

any preferential zones (inhomogeneities or cracks) and quartz/carbonate intergrowth textures are always sharply cut-off on boundaries of individual types.

We observed neither alteration fronts, which can be seen in other parts of the drilling (e.g., carbonatized trachytes, carbonatized sandstones), nor any leaching haloes, well developed in other altered rocks of the R2 drilling. The alteration is also evoked by the presence of pyrite. Pyrite obviously is of secondary origin in the breccia facies, where it is strongly concentrated along the interaction resulted in formation of the early-crystallized mixed D-P silicocarbonatite autholiths enclosed by the silicaterich (S-type) silicocarbonatite (Fig. 2b, Fig. 3).

The "pseudobreccia" textures may commonly reflect a non-homogeneous alteration with "clasts" of the fresh rock enclosed in "matrix" of the alteration product (McPhie et al. 1993). Such a process may explain the high content of quartz, with different proportions in individual types. On the other hand, the quartz is present in all types of silicocarbonatite with approximately the same grain size (Figs 2 and 3). The distribution of quartz does not follow

Tab. 4 Isotope compositions of $\mathrm{Sr}, \mathrm{Nd}$ and $\mathrm{Pb}$ in the $\mathrm{R} 2$ silicocarbonatite: whole-rock, carbonate (CF) and non-carbonate (NCF) fractions

\begin{tabular}{|c|c|c|c|}
\hline & Bulk & CF & NCF \\
\hline${ }^{87} \mathrm{Sr} /{ }^{86} \mathrm{Sr}$ & $0.706238 \pm 09$ & $0.706113 \pm 12$ & $0.707716 \pm 15$ \\
\hline${ }^{87} \mathrm{Sr} /{ }^{86} \mathrm{Sr}_{30}$ & 0.70615 & 0.70610 & 0.70622 \\
\hline${ }^{143} \mathrm{Nd} /{ }^{144} \mathrm{Nd}$ & $0.512067 \pm 05$ & $0.512069 \pm 05$ & $0.512071 \pm 17$ \\
\hline${ }^{143} \mathrm{Nd} /{ }^{144} \mathrm{Nd}_{30}$ & 0.512045 & 0.512047 & 0.512047 \\
\hline$\varepsilon_{\mathrm{Nd} 30}$ & -10.8 & -10.8 & -10.7 \\
\hline replicate TIMS & $0.512041 \pm 9$ & $0.512060 \pm 9$ & \\
\hline${ }^{206} \mathrm{~Pb} /{ }^{204} \mathrm{~Pb}$ & $18.982 \pm 02$ & $18.839 \pm 29$ & $19.202 \pm 05$ \\
\hline${ }^{207} \mathrm{~Pb} /{ }^{204} \mathrm{~Pb}$ & $15.630 \pm 17$ & $15.548 \pm 26$ & $15.654 \pm 08$ \\
\hline${ }^{208} \mathrm{~Pb} /{ }^{204} \mathrm{~Pb}$ & $38.979 \pm 04$ & $38.772 \pm 58$ & $39.092 \pm 26$ \\
\hline$\delta^{13} \mathrm{C}_{\mathrm{V}-\mathrm{PDB}}$ & $-2.46 \pm 0.04$ & & \\
\hline replicate & $-2.45 \pm 0.04$ & & \\
\hline$\delta^{18} \mathrm{O}_{\text {V-SMOW }}$ & $7.43 \pm 0.07$ & & \\
\hline replicate & $7.43 \pm 0.07$ & & \\
\hline
\end{tabular}

Analytical uncertainty of $\mathrm{Sr}, \mathrm{Nd}, \mathrm{Pb}$ isotope ratios is expressed as two standard errors of the mean (2SE(M)), for $\delta^{13} \mathrm{C}_{\mathrm{V}-\mathrm{PDB}}$ and $\delta^{18} \mathrm{O}_{\mathrm{V}-\mathrm{Smow}}$ as two standard deviations (2 sd)

subscripts ' 30 ' indicate age-corrected isotope ratios 
cracks (Fig. 2a), although it has been later hematitized. In the coherent facies, pyrite is not distributed randomly, or along inhomogeneities, but mostly concentrated in the coarser-grained P-type silicocarbonatite (Figs 2e-f).

\subsection{Bulk-rock chemistry}

The carbonatitic magmas could be generated by (i) partial melting of a mantle peridotite or eclogite, (ii) fractional crystallization from parental alkaline silicate magmas, or (iii) liquid immiscibility (Wyllie and Tuttle 1960; Le
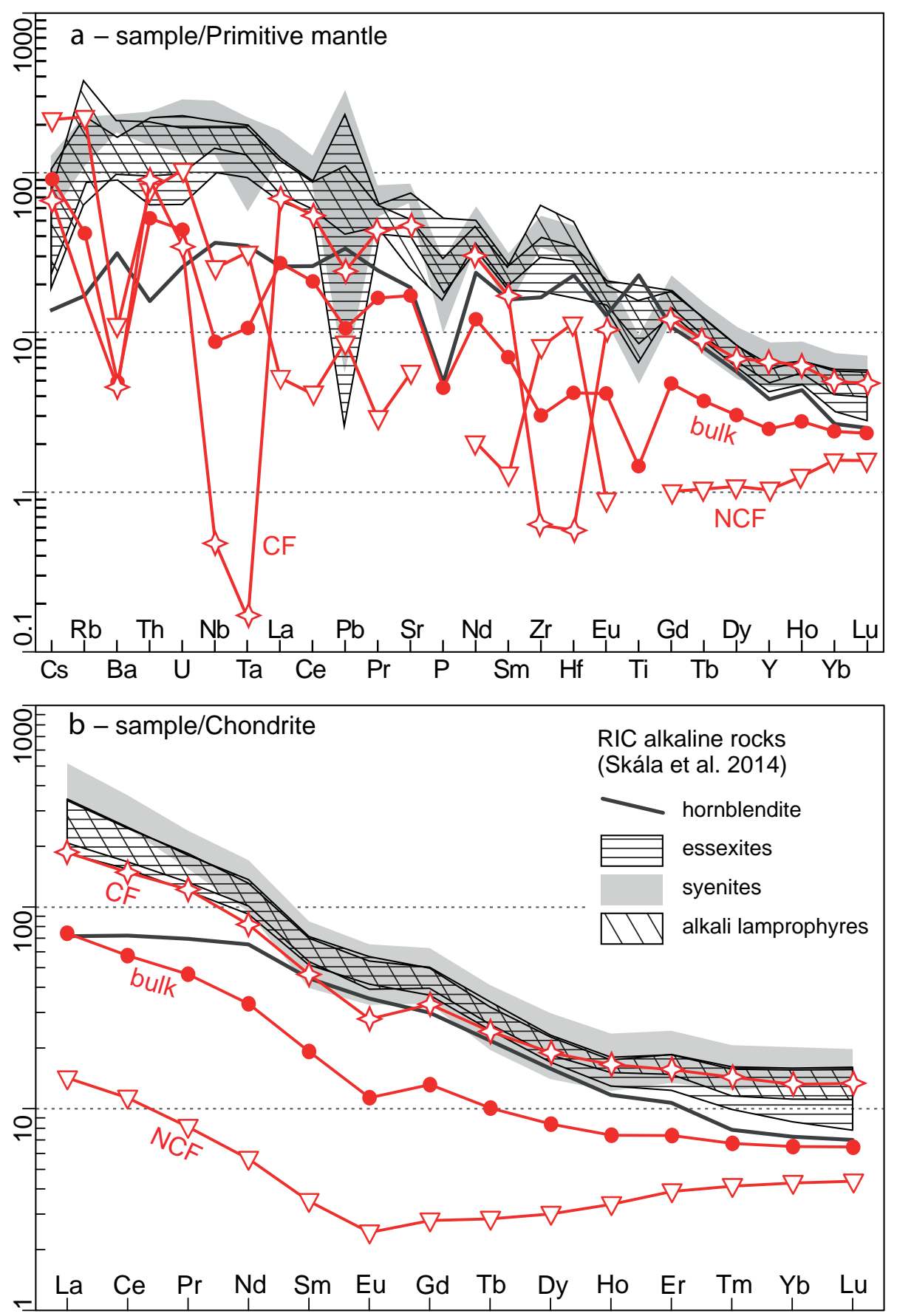

Bas 1977; Bell and Keller 1995). Lee and Wyllie (1997) concluded that most carbonatite magmas are derived from parental carbonated silicate melts by fractional crystallization at crustal levels. These authors pointed out that the carbonate liquidus represents the 'forbidden zone' in phase diagrams for initially $\mathrm{CO}_{2}$-rich silicate liquids (Hamilton et al. 1979; Fig. 5). Derivative magmas can precipitate carbonates only along the defined silicate-carbonate boundaries in the Hamilton's projection (Lee and Wyllie 1997). As shown in Fig. 5, the composition of R2 silicocarbonatite corresponds to the silicate-carbonate field boundary, where carbonate co-precipitated, indicating that R2 silicocarbonatite should be magmatic in origin. It could also be classified as 'primary carbonatite' on the basis of its high $\mathrm{Mg \#}$ [molar $\mathrm{MgO} /(\mathrm{MgO}$ $\left.+\mathrm{FeO}_{\text {tot }}\right)=67.8$ ]. According to Eggler (1989), primary carbonatite magmas should have Mg\# $>$ 64. We note here, however, that this value is much lower than that of average Mg-carbonatites with $\mathrm{Mg \#}=0.81 \pm 0.08$ (Litasov and Ohtani 2009).

Relatively high Mg\# of R2 silicocarbonatite is in contrast with the presence of quartz and albite, suggesting that its parental melt should have been likely derived from extremely fractionated alkaline magma (alkali syenite). Hammouda (2003) suggested on the basis of experiments with carbonated eclogite at 5-10 GPa that $\mathrm{Ca}$ rich carbonatites $[\mathrm{Ca} \#=$ mo$\operatorname{lar} \mathrm{Ca} /(\mathrm{Ca}+\mathrm{Fe}+\mathrm{Mg}) \sim 0.80]$ are related to subduction and partial melting of carbonated eclogites. In contrast, Litasov and Ohtani (2009) concluded that carbonatites produced by

Fig. 6 Trace element concentrations normalized to: a - Primitive mantle (McDonough and Sun 1995); b - CI-chondrite (Anders and Grevesse 1989). Normalized trace element patterns of the silicocarbonatite (CF- carbonate fraction, NCF- non-carbonate residuum) from the R2 drilling $(154.4 \mathrm{~m})$ are compared with the composition of samples from the Roztoky Intrusive Complex (RIC) (from Skála et al. 2014). 

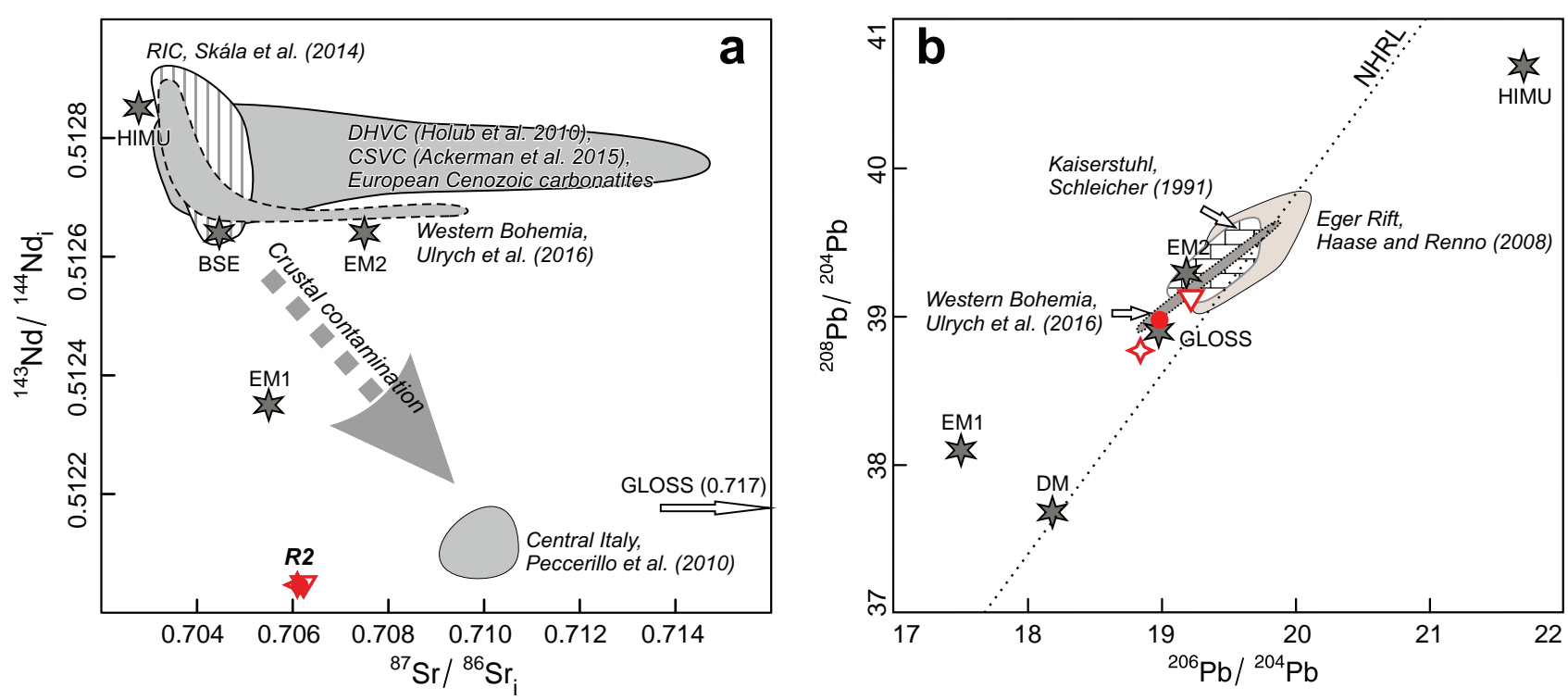

Fig. $7 \mathrm{The} \mathrm{Sr}-\mathrm{Nd}-\mathrm{Pb}$ isotope compositions of whole-rock, carbonate and non-carbonate fractions of the $\mathrm{R} 2 / 154.4 \mathrm{~m} \mathrm{silicocarbonatite:} \mathbf{a}-{ }^{87} \mathrm{Sr} /{ }^{86} \mathrm{Sr}$ vs. ${ }^{143} \mathrm{Nd} /{ }^{144} \mathrm{Nd}$ initial values. R2 silicocarbonatite data are age-corrected to $30 \mathrm{Ma}$, reference data according to the original papers. European Cenozoic carbonatites are represented by data from Kaiserstuhl (Schleicher et al. 1990), West Eifel (Riley et al. 1996) and Delitzch Complex (Krüger et al. 2013), and include also accompanying silicate rocks. Carbonatites from Central Italy (Peccerillo et al. 2010) have Quaternary age. Unlike R2 silicocarbonatite, the carbonatites from Central Italy have Sr-Nd isotope compositions similar to the associated silicate rocks. $\mathbf{b}-{ }^{206} \mathrm{~Pb} /{ }^{204} \mathrm{~Pb} v s$. ${ }^{208} \mathrm{~Pb} /{ }^{204} \mathrm{~Pb}$ measured values. HIMU, EM1, EM2, DM data from Zindler and Hart (1986). NHRL - Northern Hemisphere Reference Line (Hart 1984). The average isotope composition of GLOSS (global subducting sediments) is from Plank and Langmuir (1998). Reservoirs are not age-corrected.

melting of carbonated peridotites have moderate Ca\# values (0.3-0.5). The R2 silicocarbonatite has Ca\# = 0.87 , compatible with the former scenario. However, the original Ca\# could be obscured by polyphase evolution of the studied rock (Fig. 3). The magmatic origin of the R2 silicocarbonatite is further supported by the calcite-dolomite thermometer (Rice 1977) yielding temperatures of carbonatite formation between 660 and $800{ }^{\circ} \mathrm{C}$ (Tab. 1). These values correspond to mantle conditions, where Mg-rich calcite, dolomite, and magnesite are known to be stable (Kraft et al. 1991).

The REE pattern of the CF of R2/154.4 mimics that of alkaline rocks of the Roztoky Intrusive Complex investigated by Skála et al. (2014; Fig. 6b). The overall low REE content in comparison with most carbonatites worldwide (Jones et al. 2013) probably reflects their low abundance in the carbonatite source; rather low total REE contents of $c$. 80 ppm were also reported from other intrusive carbonatites (e.g., Chakhmouradian et al. 2016). Thorium/uranium, $\mathrm{Zr} / \mathrm{Hf}$ and $\mathrm{Nb} / \mathrm{Ta}$ ratios are elevated in the CF over the NCF (Tab. 3) and common mantle values, which is consistent with their general behaviour in such systems (Bizimis et al. 2003; Chakhmouradian 2006).

\subsection{Radiogenic and stable isotope composition}

The initial Sr-Nd isotope compositions of the three analyzed samples are almost indistinguishable $\left(\varepsilon_{\mathrm{Nd} 30}\right.$ $\left.\sim-10.8 ;{ }^{87} \mathrm{Sr} /{ }^{86} \mathrm{Sr}_{30} \sim 0.7061-0.7062\right)$. This provides evidence for common origin of both fractions, again underscoring their magmatic origin. On the other hand, it differs significantly from most other carbonatite occurrences worldwide, which usually carry significantly more primitive, mantle-like $\mathrm{Sr}-\mathrm{Nd}$ isotope signature (often between HIMU and EM-1 composition; Bell and Bleinkinsop 1987; Schleicher et al. 1990; Kramm 1993; Jones et al. 2013).

However, even more radiogenic Sr and less radiogenic $\mathrm{Nd}$ isotope systematics than those found for R2 silicocarbonatite have been observed for carbonatites from Shandong, China, which was explained by their derivation from enriched lithospheric mantle that had been previously modified by subduction (Ying et al. 2004). The Sr-Nd isotope signature of R2 is also strikingly different from both primitive and evolved Cenozoic alkaline volcanic rocks in the Bohemian Massif (e.g., Haase and Reno 2008; Holub et al. 2010; Ackerman et al. 2015; Ulrych et al. 2016; Fig. 7a). Generally, there are two possible explanations for the anomalous $\mathrm{Sr}-\mathrm{Nd}$ isotope composition of the studied sample: isotopically evolved crust-like source, or late contamination by post-magmatic fluids. The latter explanation is less plausible because REE are not readily soluble in aqueous fluids in silicate and carbonate environments (Song et al. 2016). Also the scenario of assimilation of Cretaceous sedimentary country rocks can be excluded because Nd concentrations in these sediments vary between 3 and 7 ppm, rarely 
up to $14 \mathrm{ppm}$ (unpublished data of the authors). Therefore, a more probable explanation for the radiogenic $\varepsilon_{\mathrm{Nd}}$ signature seeks the origin of R2 silicocarbonatite in an isotopically evolved environment of enriched lithospheric mantle (e.g., Janoušek et al. 1995).

The range of $\mathrm{Pb}$ isotope data for $\mathrm{R} 2$ silicocarbonatite falls between the EM1 and HIMU component (Fig. 7b). The $\mathrm{Pb}$ isotope composition of NCF is close to the composition of silicate rocks from the Eger Rift (Haase and Renno 2008; Ulrych et al. 2016) and EM2 component. However, the $\mathrm{Pb}$ isotope composition of CF is similar to the field of GLOSS (global subducting sediments; Plank and Langmuir 1998). This fact could be explained by the influence of recycled sedimentary material, as described by Yang et al. (2014) for western Tianshan.

The stable $\mathrm{C}-\mathrm{O}$ isotope composition of carbonate fraction of the R2 silicocarbonatite is, to some extent, remarkable in having a relatively ${ }^{13} \mathrm{C}$-enriched signature at a given $\delta^{18} \mathrm{O}$ value (Fig. 8). The $\delta^{18} \mathrm{O}_{\text {v-sMow }}=7.4 \%$ would correspond to Primary Igneous Carbonatites (PIC: Taylor et al. 1967). The values observed in the $\mathrm{R} 2$ silicocarbonatite are less common for primary mantle-derived igneous carbonatites but can be associated with metasomatic overprints by $\mathrm{CO}_{2}$ released from a subducted slab, as advocated for Turiy Mys (Demény et al. 2004), for example. Indeed, an older subduction event ( $\sim 370-350$ $\mathrm{Ma}$ ) has been evidenced in north-western part of the Bohemian Massif (Schulmann et al. 2009, 2014), thereby possibly introducing necessary quantities of $\mathrm{CO}_{2}$ into the source region of the R2 silicocarbonatite.

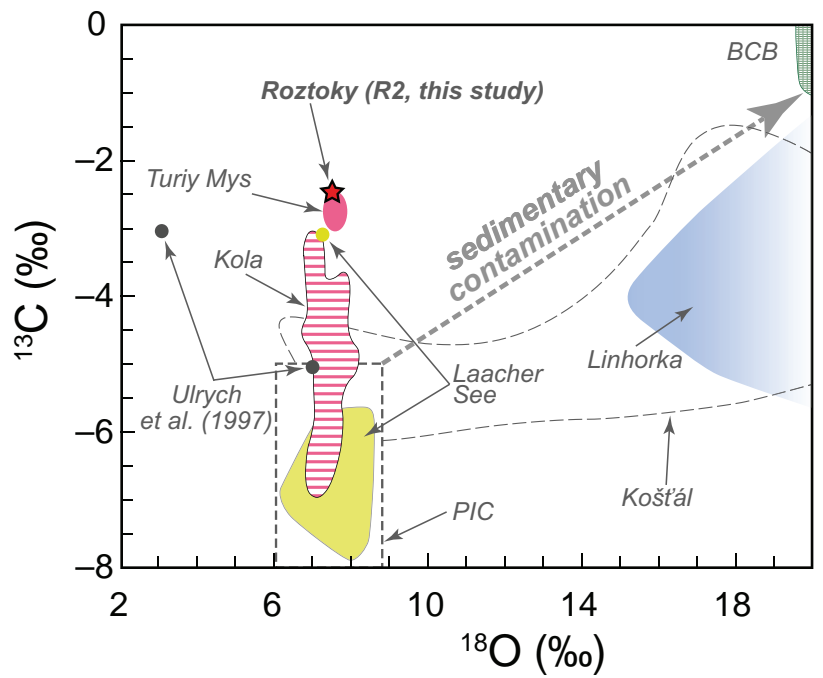

Fig. 8 The C-O isotope data from R2/154.4 m silicocarbonatite compared with data from carbonates in alkaline volcanic rocks of the Bohemian Massif (Košt’ál xenoliths: Kopecký et al. 1984; Linhorka xenoliths: Mihaljevič 1988; magmatic carbonates in various dykes: Ulrych et al. 1997), carbonatites in Kola and Turiy Mys region (Demény et al. 2004), Laacher See (Taylor et al. 1967; Riley et al. 1996, 1999), primary igneous carbonatite field (PIC: Ray and Ramesh 2006), and composition of Bohemian Cretaceous Basin sediments (BCB: Uličný et al. 2014).
Several previously published $\mathrm{C}-\mathrm{O}$ isotope data from xenoliths in the Koštál conduit (Kopecký et al. 1984) and Linhorka diatreme (Mihaljevič 1988) display a clear mixing trend between primary igneous and sedimentary rocks (Fig. 8). In contrast, from Fig. 8 it follows that contamination by sedimentary lithologies from the Bohemian Cretaceous Basin in our case is largely excluded given their ${ }^{13} \mathrm{C}-{ }^{18} \mathrm{O}$-enriched signature (Uličný et al. 2014). We note that the $\mathrm{C}-\mathrm{O}$ isotope compositions of carbonatites from Eifel (Taylor et al. 1967; Riley et al. 1996, 1999) and Kola Peninsula (Demény et al. 2004) also plot towards ${ }^{13} \mathrm{C}$-enriched composition, similar to the R2 silicocarbonatite (Fig. 8). In general, the same trend is followed by magmatic carbonates enclosed within several alkaline silicate rocks of the Bohemian Massif (Ulrych et al. 1997). Alternatively, the increased $\delta^{13} \mathrm{C}$ value $(-2.5$ $\%$ ) could be interpreted in terms of $\mathrm{CO}_{2}$-rich influx. Such an overprint would result in loss of REE such as described from carbonatites in southern India (Ackerman et al. 2017) but shifts towards more positive $\delta^{18} \mathrm{O}$ would likely be observed.

Further studies will require application of advanced microanalytical techniques applicable also for isotope systems and focusing on individual batches at microscopic scale (e.g., microdrill, laser ablation). Even though the present study of the newly discovered R2 silicocarbonatite leaves many questions open, it also holds promise for earning more knowledge about relation of carbonate and silicic melts and their country rocks in continental rift settings.

\section{Conclusions}

- We report on the first direct find of carbonatite in central Europe, associated with Cenozoic alkaline magmatism, from the Roztoky Intrusive Complex (RIC) in Eger Rift (NW Bohemian Massif).

- The investigated silicocarbonatite in the R2 drill-core is of magmatic origin (formation temperatures 660 $800^{\circ} \mathrm{C}$ ), as evidenced by textures and calcite-dolomite thermometry.

- Based on the annealed inhomogeneous texture of the R2 silicocarbonatite, i.e., three distinct textural types, we propose a scenario comprising interplay of three batches of silicocarbonatite magma.

- The presence of quartz and albite would imply a possible origin by extreme fractionation of highly differentiated $\mathrm{CO}_{2}$-saturated alkaline magma (like alkali syenites of the RIC). However, $\mathrm{Mg} \#$ of $\sim 68$ and isotope ratios of $\mathrm{Sr}$ and $\mathrm{Nd}\left({ }^{87} \mathrm{Sr} /{ }^{86} \mathrm{Sr}_{30} \sim 0.7062,{ }^{143} \mathrm{Nd} /{ }^{144} \mathrm{Nd}_{30}\right.$ $=0.51205$ ), distinct from published RIC values, rather point to an independent source, possibly an enriched lithospheric mantle beneath the NW Bohemian Massif. 
- The $\mathrm{Pb}$ isotope composition of the $\mathrm{R} 2$ silicocarbonatite is not inconsistent with the hypothesis of the origin from the recycled subducted sediments.

- The stable isotope data $\left(\delta^{13} \mathrm{C}_{\text {V-PDB }}=-2.5 \%, \delta^{18} \mathrm{O}_{\text {V-SMow }}\right.$ $=7.4 \%$ ) exclude a significant role of Cretaceous sediments in the petrogenesis of R2 silicocarbonatite.

Acknowledgements. We are indebted to R. Šarič for help with locating the R2 drill-core in the Czech Geological Survey storage. This work was financed by the Czech Science Foundation project no. 15-08583S. The development of the XRD-methodology was supported by the internal project no. 339400 of the Czech Geological Survey. Special thanks are due to V. Erban for help with radiogenic isotope analyses, and isotope data interpretations. The manuscript benefited from constructive comments by J. Kynický and L. Krmíček, as well as from editorial handling by E. Jelínek.

\section{References}

Ackerman L, Ulrych J, Řanda Z, Erban V, Hegner E, Magna T, Balogh K, Frána J, Lang M, Novák JK (2015) Geochemical characteristics and petrogenesis of phonolites and trachytic rocks from the České Středohoří Volcanic Complex, the Ohře Rift, Bohemian Massif. Lithos 224: 256-271

ACKerman L, Magna T, Rapprich V, Upadhyay D, KoChergina Y, KrátKÝ O, ČEJKová B, Erban V, HrstKa $\mathrm{T}$ (2017) Contrasting petrogenesis of spatially related carbonatites from Samalpatti and Sevattur, Tamil Nadu, India. Lithos 284-285: 257-275

Anders E, Grevesse N (1989) Abundances of the elements: meteoritic and solar. Geochim Cosmochim Acta 53: 197-214

Becker RH, Clayton RN (1976) Oxygen isotope study of a Precambrian Banded Iron-Formation, Hamersley Range, Western-Australia. Geochim Cosmochim Acta 40: 1153-1165

Bell K, Blenkinsop J (1987) Nd and Sr isotopic compositions of East African carbonatites: implications for mantle heterogeneity. Geology 15: 99-102

Bell K, Keller J (1995) Carbonatite Volcanism. Springer, Berlin, pp 1-210

Bish DL, Von DreELE RB (1989) Rietveld refinement of non hydrogen atomic positions in kaolinite. Clays Clay Miner 37: 289-296

Bizimis M, Salters VJ, Dawson JB (2003) The brevity of carbonatite sources in the mantle: evidence from $\mathrm{Hf}$ isotopes. Contrib Mineral Petrol 145: 281-300

Brooker RA (1998) The effect of $\mathrm{CO}_{2}$ saturation on immiscibility between silicate and carbonate liquids: an experimental study. J Petrol 39: 1905-1915
Bruker AXS (2014) Topas 5. Karlsruhe, Germany

Cajz V, Vokurka K, Balogh K, Lang M, Ulrych J (1999) The České Středohoří Mts.: volcanostratigraphy and geochemistry. Geolines 9: 21-28

CAJZ V, Rapprich V, ERban V, PÉCSKay Z, RAdoñ M (2009) Late Miocene volcanic activity in the České Středohoří Mountains (Ohře/Eger Graben, northern Bohemia). Geol Carpath 60: 519-533

Chakhmouradian AR (2006) High-field-strength elements in carbonatitic rocks: geochemistry, crystal chemistry and significance for constraining the sources of carbonatites. Chem Geol 235: 138-160

Chakhmouradian AR, Reguir EP, Zaitsev AN (2016) Calcite and dolomite in intrusive carbonatites. I. Textural variations. Mineral Petrol 110: 333-360

Chen W, Simonetti A (2013) In-situ determination of major and trace elements in calcite and apatite, and $\mathrm{U}-\mathrm{Pb}$ ages of apatite from the Oka carbonatite complex: insights into a complex crystallization history. Chem Geol 353: 151-172

Demény A, Sitnikova MA, Karchevsky PI (2004) Stable $\mathrm{C}$ and $\mathrm{O}$ isotope compositions of carbonatite complexes of the Kola Alkaline Province: phoscorite-carbonatite relationships and source compositions. In: WALL F, ZAITSEV AN (eds) Phoscorites and Carbonatites: from Mantle to Mine. The Mineralogical Society Series 10: 407-431

Dempírová L, ŠIKL J, KAŠIČKOVÁ R, Zoulková V, KŘíBEK $B$ (2010) The evaluation of precision and relative error of the main components of silicate analyses in Central Laboratory of the Czech Geological Survey. Zpr Geol Výzk v Roce 2009: 326-330 (in Czech)

EGGLER DH (1989) Carbonatites, primary melts, and mantle dynamics. In Bell K (ed) Carbonatites: Genesis and Evolution. Unwin Hyman, London, pp 500-545

Ferguson RB, Traill RJ, TAYlor WH (1958) The crystal structures of low-temperature and high-temperature albites. Acta Crystallogr 11: 331-348

Finklea SL III, Cathey L, Amma EL (1976) Investigation of the bonding mechanism in pyrite using the Mössbauer effect. Acta Crystallogr A32: 529-537

FrÝDA J, VOKURKA K (1995) Evidence for carbonatite metasomatism in the upper mantle beneath the Bohemian Massif. J Czech Geol Soc 40: 9-10

HAASE KM, RENNO AD (2008) Variation of magma generation and mantle sources during continental rifting observed in Cenozoic lavas from the Eger Rift, Central Europe. Chem Geol 257: 192-202

Haloda J, Rapprich V. Holub FV, Halodová P, Vaculovič $\mathrm{T}$ (2010) Crystallization history of ijolitic rocks from the Doupovské hory Volcanic Complex (Oligocene, Czech Republic). J Geosci 55: 279-297

Hamilton DL, Freestone IC, Dawson JB, Donaldson CH (1979) Origin of carbonatites by liquid immiscibility. Nature 279: 52-54 
Hammouda T (2003) High-pressure melting of carbonated eclogite and experimental constraints on carbon recycling and storage in the mantle. Earth Planet Sci Lett 214: 357-368

HART S (1984) A large-scale isotope anomaly in the Southern Hemisphere mantle. Nature 309: 753-757

Holub FV, Rapprich V, Erban V, Pécskay Z, Mlčoch B, Míková J (2010) Petrology and geochemistry of the Tertiary alkaline intrusive rocks at Doupov, Doupovské hory Volcanic Complex (NW Bohemian Massif). J Geosci 55: 251-278

JACOBSEN SB, WASSERBURG GJ (1980) Sm-Nd isotopic evolution of chondrites. Earth Planet Sci Lett 50: 139-155

JANOUŠEK V, RoGERS G, BowES DR (1995) Sr-Nd isotopic constraints on the petrogenesis of the Central Bohemian Pluton, Czech Republic. Geol Rundsch 84: 520-534

JANOUŠEK V, FARROW CM, ERBAN V (2006) Interpretation of whole-rock geochemical data in igneous geochemistry: introducing Geochemical Data Toolkit (GCDkit). J Petrol 47: 1255-1259

JelíNeK E, SOUČEK J, TvRdÝ J, Ulrych J (1989) Geochemistry and petrology of alkaline dyke rocks of the Roztoky volcanic centre, České Středohoří Mts., ČSSR. Chem Erde 49: 201-217

Jochum KP, Nohl U, Herwig K, Lammel E, Stoll B, HofmanN AW (2005) GeoReM: a new geochemical database for reference materials and isotopic standards. Geostand Geoanal Res 29: 333-338

Jones AP, Genge M, CARMOdy L (2013) Carbonate melts and carbonatites. In: HAZEN RM, JONES AP, BAROSS JA (eds) Carbon in Earth. Mineralogical Society of America and Geochemical Society Reviews in Mineralogy and Geochemistry 75: 289-322

Kim S, Coplen TB, Horita J (2015) Normalization of stable isotope data for carbonate minerals: implementation of IUPAC guideline. Geochim Cosmochim Acta 158: $276-289$

KoPECKÝ L (1987-88) Young volcanism of the Bohemian Massif. Geol Hydrometal Uranu, 11(3): 30-67; 11(4): $3-44 ; 12(1): 3-40 ; 12(2): 3-56 ; 12(3): 3-40 ; 12(4)$ : 3-40 (in Czech)

KopeckÝ L (2010) České Středohoří Mts. and Ambient Young Alkaline Volcanic Complexes in the Ohře Rift, Czech Republic: Volcanology, Petrology and Rift Evolution. Czech Geological Survey, Prague, pp 1-188

KOPECKÝ L, ŠMEJKAL V, HLAdÍKOvá J (1984) Isotopic composition and origin of carbonates in alkaline-metasomatic and cognate rocks of the Bohemian Massif, Czechoslovakia. In: KopeckÝ L (ed) Proceedings of the First Seminar on Carbonatites and Alkaline Rocks of the Bohemian Massif and Ambient Regions. Czech Geological Survey, Prague, pp 177-196

Kraft S, Knittle E, Williams Q (1991) Carbonate stability in the Earth's mantle: a vibrational spectroscopic study of aragonite and dolomite at high pressures and temperature. J Geophys Res 96: 17997-18009

Kramm U (1993) Mantle components of carbonatites from the Kola Alkaline Province, Russia and Finland: a Nd-Sr study. Eur J Mineral 5: 985-989

KRÜGER JC, Romer RL, KÄMPF H (2013) Late Cretaceous ultramafic lamprophyres and carbonatites from the Delitzsch Complex, Germany. Chem Geol 353: 140-150

LE BAs MJ (1977) Carbonatite-Nephelinite Volcanism: An African Case History. John Wiley \& Sons, London, pp 1-347

Le Page Y, Donnay G (1976) Refinement of the crystal structure of low-quartz. Acta Crystallogr B 32: 2456-2459

LEE WJ, WylLIE PJ (1997) Liquid immiscibility between nephelinite and carbonatite from 1.0 to $2.5 \mathrm{GPa}$ compared with mantle melt compositions. Contrib Mineral Petrol 127: $1-16$

Litasov KD, OHTANi E (2009) Solidus and phase relations of carbonated peridotite in the system $\mathrm{CaO}-\mathrm{Al}_{2} \mathrm{O}_{3}-\mathrm{MgO}-$ $\mathrm{SiO}_{2}-\mathrm{Na}_{2} \mathrm{O}-\mathrm{CO}_{2}$ to the lower mantle depths. Phys Earth Planet Inter 177: 46-58

LugMaIr GW, MARTI K (1978) Lunar initial ${ }^{143} \mathrm{Nd} /{ }^{144} \mathrm{Nd}$ : differential evolution line of the lunar crust and mantle. Earth Sci Lett 39: 349-357

Lustrino M, WiLsOn M (2007) The circum-Mediterranean anorogenic Cenozoic igneous province. Earth Sci Rev 81: $1-65$

MARKGRAF SA, REEDER RJ (1985) High-temperature structure refinements of calcite and magnesite. Am Mineral 70: 590-600

Martin LHJ, Schmidt M, Mattsson HB, Ulmer P, HAMETNER K, GÜNTHER D (2012) Element partitioning between immiscible carbonatite-kamafugite melts with application to the Italian ultrapotassic suite. Chem Geol 320-321: 96-112

MCCREA JM (1950) On the isotopic chemistry of carbonates and a paleotemperature scale. J Chem Phys 18: 849-857

McDonough WF, Sun SS (1995) The composition of the Earth. Chem Geol 120: 223-253

McPhie J, Doyle M, Allen R (1993) Volcanic Textures: A Guide to the Interpretation of Textures in Volcanic Rocks. CODES, Hobart, Tasmania, pp 1-198

Minaljevič M (1988) Geochemistry of the Pipe Breccia at the Linhorka Hill near Třebenice. Unpublished MSci. Thesis, Charles University, Prague, pp 1-61 (in Czech)

Mrlina J, CAJZ V (2006) Subsurface structure of the volcanic centre of the České Středohoří Mountains, North Bohemia, determined by geophysical survey. Stud Geophys Geodet 50: 75-88

Peccerillo A, Federico M, Barbieri M, Brilli M, Wu TW (2010) Interaction between ultrapotassic magmas and carbonate rocks: evidence from geochemical and isotopic (Sr, Nd, O) compositions of granular lithic clasts 
from the Alban Hills Volcano, Central Italy. Geochim Cosmochim Acta 74: 2999-3022

Pin C, Gannoun A, Dupont A (2014) Rapid, simultaneous separation of $\mathrm{Sr}, \mathrm{Pb}$, and $\mathrm{Nd}$ by extraction chromatography prior to isotope ratios determination by TIMS and MC-ICP-MS. J Anal At Spectrom 29: 1858-1870

Pivec E, Ulrych J, Šrein V, Bendl J, Dobeš P, Žák K (1998) Epithermal Tertiary $\mathrm{Pb}-\mathrm{Zn}-\mathrm{Cu}$ (Ag, Te) mineralization in the Roztoky Volcanic Centre, České Středohoří Mts., Czech Republic. Geol Carpath 49: 139-146

Plank T, Langmuir CH (1998) The chemical composition of subducting sediment and its consequences for the crust and mantle. Chem Geol 145: 325-394

RAY JS, RAMESH R (2006) Stable carbon and oxygen isotopic compositions of Indian carbonatites. Int Geol Rev 48: 17-45

RAYNER JH (1974) The crystal structure of phlogopite by neutron diffraction. Mineral Mag 39: 850-856

REEDER RJ, DOLlase WA (1989) Structural variation in the dolomite-ankerite solid-solution series: an X-ray, Mössbauer, and TEM study. Am Mineral 74: 1159-1167

RicE JM (1977) Contact metamorphism of impure dolomitic limestone in the Boulder aureole, Montana. Contrib Mineral Petrol 59: 237-259

Riley TR, BAiley DK, Lloyd FE (1996) Extrusive carbonatite from the Quaternary Rockeskyll Complex, West Eifel, Germany. Canad Mineral 34: 389-401

Riley TR, Bailey DK, HaRmer RE, Liebsch H, Lloyd FE, PALMER MR (1999) Isotopic and geochemical investigation of a carbonatite-syenite-phonolite diatreme, West Eifel (Germany). Mineral Mag 63: 615-631

Schleicher H, Keller J, Kramm U (1990) Isotope studies on alkaline volcanics and carbonatites from the Kaiserstuhl, Federal Republic of Germany. Lithos 26: 21-35

Schulmann K, Konopásek J, Janoušek V, Lexa O, LARDEAUX JM, EdEL JB, ŠTíPSKÁ P, UlRich S (2009) An Andean type Palaeozoic convergence in the Bohemian Massif. C R Geosci 341: 266-286

Schulmann K, Lexa O, Janoušek V, Lardeaux JM, Edel JB (2014) Anatomy of a diffuse cryptic suture zone: an example from the Bohemian Massif, European Variscides. Geology 42: 275-278

Skála R, Ulrych J, Ackerman L, Jelínek E, Dostál J, Hegner E, ŘAnda Z (2014) Tertiary alkaline Roztoky Intrusive Complex, České Středohoři Mts., Czech Republic: petrogenetic characteristics. Int J Earth Sci (Geol Rundsch) 103:1233-1262

Song WL, Xu C, Veksler IV, Kynický J (2016) Experimental study of REE, Ba, Sr, Mo and W partitioning between carbonatitic melt and aqueous fluid with implications for rare metal mineralization. Contrib Mineral Petrol 171: 1-12

SteIGER RH, JÄGER E (1977) Subcommission on Geochronology; convention on the use of decay constants in geoand cosmochronology. Earth Planet Sci Lett 36: 359-362
Stoppa F, SchiazZa M (2013) An overview of monogenetic carbonatitic magmatism from Uganda, Italy, China and Spain: volcanologic and geochemical features. J South Am Earth Sci 41: 140-159

Tappe S, Foley SF, Jenner GA, Heaman LM, KJarsgaArd BA, Romer RL, Stracke A, Joyce N, Hoefs J (2006) Genesis of ultramafic lamprophyres and carbonatites at Aillik Bay, Labrador: a consequence of incipient lithospheric thinning beneath the North Atlantic Craton. J Petrol 47: 1261-1315

Taylor HP, Frechen J, Degens ET (1967) Oxygen and carbon isotope studies of carbonatites from the Laacher See District, West Germany and the Alnö District, Sweden. Geochim Cosmochim Acta 31: 407-430

UličNÝ D, JaRVIS I, GRÖCKE DR, ČECH S, LAURIN J, Olde K, Trabucho-Alexandre J, Švábenická L, Pedentchouk $\mathrm{N}$ (2014) A high-resolution carbon-isotope record of the Turonian stage correlated to a siliciclastic basin fill: implications for mid-Cretaceous sea-level change. Palaeogeogr Palaeoclimatol Palaeoecol 405: 42-58

ULRYCH J (1998) Geochemistry of subvolcanic alkaline rocks series of the Roztoky Intrusive Centre, České Středohoří Mts., Bohemia. Erlangen Beitr Petrogr Mineral 8:1-42

UlRYCH J, BALOGH K (2000) Roztoky Intrusive Centre in the České Středohoři Mts.: differentiation, emplacement, distribution, orientation and age of dyke series. Geol Carpath 51: 383-397

Ulrych J, Pivec E, Fiala J, Lang M (1983) Petrology of the alkaline subvolcanic rocks from the Roztoky area (České Středohoří Mts.). Rozpr Čs Akad Věd, Ř Mat prír věd 93: pp 1-84

Ulrych J, Pivec E, Žák K, Bendl J, Bosák P (1993) Alkaline and ultramafic carbonate lamprophyres in Central Bohemian Carboniferous Basins, Czech Republic. Mineral Petrol 48: 65-81

Ulrych J, Pivec E, Povondra P, Bendl J (1997) Geochemical and isotope characteristics of representative carbonates in young alkaline volcanites from northern Bohemia. J Czech Geol Soc 42: 26-32

Ulrych J, Svobodoví J, Balogh K (2002) The source of Cenozoic volcanism in the České Středohoří Mts., Bohemian Massif. Neu Jb Mineral, Abh 177: 133-162

Ulrych J, Lloyd FE, Balogh K, Hegner E, Langrová A, LANG M, NováK JK, ŘAnda Z (2005) Petrogenesis of alkali pyroxenite and ijolite xenoliths from the Tertiary Loučná-Oberwiesenthal Volcanic Centre, Bohemian Massif in the light of new mineralogical, geochemical, and isotopic data. Neu Jb Mineral, Abh 182: 57-79

Ulrych J, Dostál J, Adamovič J, JeLínek E, ŠpaČek P, Hegner E, Balogh K (2011) Recurrent Cenozoic volcanic activity in the Bohemian Massif (Czech Republic). Lithos 123: 133-144

Ulrych J, AdAmovič J, Krmíček L, Ackerman L, Balogh K (2014) Revision of Scheumann's classification of mel- 
ilitic lamprophyres and related melilitic rocks in light of new analytical data. J Geosci 59: 3-22

Ulrych J, KrmíčeK L, TOMEK Č, LlOYD FE, LADENBERGER A, Ackerman L, Balogh K (2016) Petrogenesis of Miocene alkaline volcanic suites from western Bohemia: whole rock geochemistry and $\mathrm{Sr}-\mathrm{Nd}-\mathrm{Pb}$ isotopic signatures. Chem Erde 76: 77-93

Veksler IV, Petibon C, Jenner GA, Dorfman AM, Dingwell DB (1998) Trace element partitioning in immiscible silicate-carbonate liquid systems: an initial experimental study using a centrifuge autoclave. J Petrol 39: 2095-2104

Wilson M, Downes H (2006) Tertiary-Quaternary intraplate magmatism in Europe and its relationship to mantle dynamics. In: GeE DG, StePhenson RA (eds) European Lithosphere Dynamics. Geological Society London Memoirs 32: 147-166

WimmenAUER W (1974) The alkaline province of central Europe and France. In: Sørensen, H. (ed.) The Alkaline Rocks. Wiley, London, pp 238-271
Woolley AR, KJARsgaArd BA (2008) Carbonatite occurrences of the world: map and database. Geological Survey of Canada, Open Files 5796, pp 1-28

Wyllie PJ, Tuttle OF (1960) The system CaO- $\mathrm{CO}_{2}-\mathrm{H}_{2} \mathrm{O}$ and the origin of carbonatites. J Petrol 1: 1-46

Yang W, Jolivet M, Dupont-Nivet G, Guo Z (2014) Mesozoic-Cenozoic tectonic evolution of southwestern Tian Shan: evidence from detrital zircon $\mathrm{U} / \mathrm{Pb}$ and apatite fission track ages of the Ulugqat area, Northwest China. Gondwana Res 26: 986-1008

Ying J, Zhou X, Zhang H (2004) Geochemical and isotopic investigation of the Laiwu-Zibo carbonatites from western Shandong Province, China, and implications for their petrogenesis and enriched mantle source. Lithos 75: 413-426

Young RA (2000) The Rietveld Method. Oxford University Press, Oxford, pp 1-312

Zindler A, Hart S (1986) Chemical geodynamics. Ann Rev Earth Planet Sci 14: 493-571 